\title{
Repeated intrauterine infusions of lipopolysaccharide alter gene expression and lifespan of the bovine corpus luteum
}

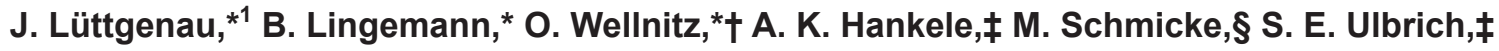 \\ R. M. Bruckmaier,† and H. Bollwein* \\ ${ }^{*}$ Clinic of Reproductive Medicine, Vetsuisse Faculty, University of Zurich, Winterthurerstrasse 260, CH-8057 Zurich, Switzerland \\ †Veterinary Physiology, Vetsuisse Faculty, University of Bern, CH-3001 Bern, Switzerland \\ ‡ETH Zurich, Animal Physiology, Institute of Agricultural Sciences, $\mathrm{CH}-8092$ Zurich, Switzerland \\ $\S$ Clinic for Cattle, University of Veterinary Medicine Hannover, D-30173 Hannover, Germany
}

\begin{abstract}
Inflammation of the uterus is associated with disturbed ovarian function and reduced reproductive performance in dairy cows. To investigate the influence of endometritis on the bovine corpus luteum, 8 heifers received intrauterine infusions with either phosphatebuffered saline (PBS; $9 \mathrm{~mL}$ ) or Escherichia coli lipopolysaccharide (LPS; $3 \mu \mathrm{g} / \mathrm{kg}$ of body weight diluted in $9 \mathrm{~mL}$ of PBS) at 6 -h intervals from $12 \mathrm{~h}$ before and until $9 \mathrm{~d}$ after ovulation during 2 cycles in a random order (ovulation $=\mathrm{d} 1$ ). An untreated cycle was examined before and after PBS and LPS cycles, and the mean values from both untreated cycles were used as control. In all cycles, blood sampling and ultrasonography of the ovaries were performed on d $0,1,2,4,6,8,9,10,12$, 15,18 , and then every $2 \mathrm{~d}$ until ovulation. Endometrial cells were collected for cytology and quantitative realtime reverse transcriptase PCR on d 0,6, and 9, and on d 0 and 6 , respectively, and luteal tissue was collected for quantitative real-time reverse transcriptase PCR on d 6 and 9. Both, PBS and LPS infusions induced subclinical endometritis, which was accompanied by increased endometrial mRNA abundance of proinflammatory cytokines $I L 1 \beta, I L 8$, and tumor necrosis factor $\alpha$. Additionally, LPS challenge induced premature luteolysis, which was characterized by increased plasma concentrations of $\mathrm{PGF}_{2 \alpha}$ metabolite, decreased plasma progesterone concentrations, and reduced luteal size and blood flow compared with the control. The luteal mRNA expression of the LPS receptor TLR 4, PGE synthase, and the apoptosis-related factor $C A S P 3$ were higher, and those of steroidogenic factors $S T A R$ and $H S D 3 B$, the PGF receptor, and the angiogenic factor $V E G F A_{121}$ were lower after LPS challenge compared
\end{abstract}

Received December 22, 2015.

Accepted March 28, 2016.

${ }^{1}$ Corresponding author: jluettgenau@vetclinics.uzh.ch with the control. In conclusion, repeated intrauterine LPS infusions during the first $9 \mathrm{~d}$ of the estrous cycle alter gene expression and shorten the lifespan of the bovine corpus luteum.

Key words: corpus luteum, endometritis, endotoxin, heifer

\section{INTRODUCTION}

Inflammatory diseases of the uterus have a negative effect on reproductive performance and over the decades they contribute to the deterioration of the fertility of high-yielding dairy cows (Lopez-Gatius, 2003; Walsh et al., 2011). The prevalence of clinical metritis and endometritis between 15 and $60 \mathrm{~d}$ postpartum was $25.9 \%$ (Gautam et al., 2009), and that of subclinical endometritis between 40 and $60 \mathrm{~d}$ postpartum ranged from 26\% (Cheong et al., 2011) to 53\% (Gilbert et al., 2005). Clinical and subclinical endometritis reduced pregnancy rates at $300 \mathrm{~d}$ postpartum by approximately 13 (70 vs. 83\%; Deguillaume et al., 2012) and 26 (63 vs. 89\%; Gilbert et al., 2005) percentage units, respectively.

Apart from a direct impairment of the endometrium that reduces the pregnancy rates due to suboptimal conditions for the nidation of the embryo (Gabler et al., 2009; Gilbert, 2011), endometritis also seems to exert various indirect effects on ovarian function. Thus, an increased number of ovarian dysfunctions, such as prolonged anestrus and cystic ovarian follicles, were observed in cows with severe clinical metritis or endometritis compared with cows with an intact puerperium (Mateus et al., 2002; Tsousis et al., 2009). After intrauterine treatment with LPS, the endotoxin of gramnegative bacteria, a delayed or inhibited ovulation in cows was noticed and was associated with reduced plasma concentrations of LH and a lower LH peak (Peter et al., 1989). Therefore, systemic effects of intrauterine LPS were assumed, which interfere with the release of LH from the adenohypophysis (Battaglia et al., 2000; 
Suzuki et al., 2001). Furthermore, a delayed ovulation might be due to inhibition of estradiol production from the ovarian follicles (Suzuki et al., 2001; Shimizu et al., 2012). Consistently, the increased concentrations of LPS that were detected in the follicular fluid of cows with clinical and subclinical endometritis (Herath et al., 2007) reduced the transcription of steroidogenic enzymes in theca and granulosa cells (Herath et al., 2007; Magata et al., 2014).

In addition to the negative effects of an endometritis on ovulation and secretory function of ovarian follicles, evidence is increasing for a detrimental effect on the corpus luteum (CL). Prolonged luteal phases were observed in cows with metritis or endometritis (Opsomer et al., 2000), probably due to a reduced endometrial release of $\mathrm{PGF}_{2 \alpha}$. Furthermore, the lifespan of the CL tended to be shorter after an intrauterine application of living Escherichia coli, indicating premature luteolysis (Gilbert et al., 1990). However, in the study of Gilbert et al. (1990), an intrauterine application of LPS did not change the luteal lifespan nor the plasma concentrations of $\mathrm{PGF}_{2 \alpha}$ metabolites (PGFM) and progesterone $\left(\mathbf{P}_{4}\right)$.

In contrast to the intrauterine LPS infusion, an intravenous treatment with LPS induced a 10 -fold increase in PGFM and a transient decrease in $\mathrm{P}_{4}$ concentrations but did not induce a complete premature luteolysis (Herzog et al., 2012). The different outcome in studies that used intrauterine or intravenous LPS challenge was likely due to the different concentrations of LPS that reached the bovine CL. However, it is widely accepted that intrauterine LPS in cattle is able to intrude into the peripheral circulation (Mateus et al., 2003; Williams et al., 2007; Magata et al., 2015), possibly by passing the oviduct, by moving transmurally into the peritoneal cavity and to the bloodstream (Peter et al., 1989), or by entering the uterine wall and following the utero-ovarian pathway, whose capabilities have been reviewed (Ginther, 1974).

In contrast to the single LPS peak that was induced by treatments in most previous studies, repeated applications of LPS into the uterus maintain high concentrations for several days and can simulate a naturally occurring endometritis more reliably. Therefore, we used repeated intrauterine LPS infusions to investigate the effects of endometritis on the morphology and function of the developing CL.

\section{MATERIALS AND METHODS}

\section{Cattle}

Eight nulliparous Red Holstein $(\mathrm{n}=7)$ and Red Holstein $\times$ Limousin crossbred $(n=1)$ cows were used in the experiment. These heifers were (mean \pm SEM) $20.8 \pm 1.2$ mo old, with an estimated BW of 448.5 $\pm 8.7 \mathrm{~kg}$ (Rondo measuring tape; Hoechstmass Balzer GmbH, Sulzbach, Germany), and a BCS of 3.75 (median; scale, 1-5). All heifers were clinically healthy with no apparent reproductive abnormalities. During the experiments, the heifers were housed in a tie stall barn and fed hay, minerals, and cattle salt, with ad libitum access to water.

The experimental procedures followed the Swiss Federal Law on Animal Protection and were approved by the Committee of Animal Experiments of the Canton Fribourg, Switzerland (application 25076).

\section{Study Design}

A modified ovulation synchronization (Ovsynch) protocol was initiated after normal cyclic activity had been confirmed by ultrasonography in all heifers. This protocol consisted of $10 \mu \mathrm{g}$ of buserelin $(\mathrm{GnRH}$ analog, Receptal; MSD Animal Health GmbH, Luzern, Switzerland), $15 \mathrm{mg}$ of luprostiol $\left(\mathrm{PGF}_{2 \alpha}\right.$ analog, Prosolvin; Virbac AG, Glattbrugg, Switzerland) 7 d later, and finally $10 \mu \mathrm{g}$ of buserelin $60 \mathrm{~h}$ after $\mathrm{PGF}_{2 \alpha}$ (all treatments were given intramuscularly). The time of the second GnRH application was defined as estrus (= d 0 h 0 ). Ovulation, which occurred in all heifers until $36 \mathrm{~h}$ after the second $\mathrm{GnRH}$ treatment, was defined as d $1 \mathrm{~h} 0$.

Four estrous cycles were investigated in the heifers: one untreated cycle at the beginning, then 2 cycles in a randomized order with intrauterine infusions of either $9 \mathrm{~mL}$ of sterile PBS (Sigma-Aldrich, St. Louis, $\mathrm{MO}$ ) or $3 \mu \mathrm{g} / \mathrm{kg}$ of BW E. coli LPS (serotype O26:B6; Sigma-Aldrich) diluted in $9 \mathrm{~mL}$ of sterile PBS, and a second untreated cycle at the end of the study. Additionally, the first $9 \mathrm{~d}$ of the next cycle after the LPS cycle (NLPS) were examined. Intrauterine treatments in the PBS and the LPS cycle were performed at 6 - $h$ intervals between d $0 \mathrm{~h} 24$ and d $9 \mathrm{~h} 0$.

In all cycles, blood sampling and ultrasonography of the uterus and ovaries were performed on d $0,1,2,4$, $6,8,9,10,12,15,18$, and then every $2 \mathrm{~d}$ until ovulation. Furthermore, endometrial cells were collected for cytology and RNA extraction on d 0, 6, and 9 and on d 0 and 6 , respectively, and luteal tissue was collected for RNA extraction on $\mathrm{d} 6$ and 9 .

To control clinical health of the heifers, their rectal temperature and habitus were examined at 6 -h intervals between d 0 and 9 , and once per day during the remaining cycle. Respiratory and cardiac frequencies were investigated immediately before each ultrasonographic examination. 


\section{Preparation of Reagents and Intrauterine Application}

Phosphate-buffered saline was prepared under sterile conditions, filled at $9 \mathrm{~mL}$ in sterile syringes for single use (Omnifix 10 mL; B. Braun Medical AG, Sempach, Switzerland), closed with a combi-stopper (Henry Schein, Melville, NY), and stored at room temperature until use.

The respective dose of LPS per animal and application time was sterilely aliquoted in small amounts of PBS ( $5 \mathrm{mg}$ of LPS per $\mathrm{mL}$ of PBS), filled in micro test tubes (Eppendorf type, PP natural $1.5 \mathrm{~mL}$ plain; Vaudaux-Eppendorf AG, Schönenbuch, Switzerland), and frozen at $-20^{\circ} \mathrm{C}$ to maintain the effectiveness of LPS. The aliquot was thawed immediately before use and diluted in $9 \mathrm{~mL}$ of PBS.

Before intrauterine application, the vulva was thoroughly cleaned with dry pulp. Treatments were performed transcervically, using a uterus catheter for single use (Infusion Pipette KI-2250, Kalayjian Industries Inc., Signal Hill, CA) guided by transrectal palpation. The uterus catheter was coated with a hygienic sheath (Minitüb GmbH \& Co. KG, Tiefenbach, Germany) that was pierced through immediately before the catheter reached the cervix to avoid any transmission of vaginal flora into the uterus. After the catheter had passed through the cervix, reagents were applied into the body of the uterus.

\section{Plasma Concentrations of Cortisol, Haptoglobin, Prostaglandin $F_{2 \alpha}$ Metabolites, and Progesterone}

Immediately before each ultrasonographic examination, blood samples were collected from the coccygeal blood vessels into evacuated tubes containing EDTA as an anticoagulant (Vacuette $9 \mathrm{~mL} \mathrm{~K}_{3}$ EDTA; Greiner Bio-One, Kremsmünster, Austria), and evacuated tubes without given content (Vacuette $9 \mathrm{~mL} \mathrm{Z}$; Greiner BioOne) that were filled with $180 \mu \mathrm{L}$ of a prepared solution containing EDTA $(0.3 M)$ and acetylsalicylic acid (1\%, wt/vol), adjusted to $\mathrm{pH} 7.5$ using $\mathrm{NaOH}$ (15\%, wt/vol). Tubes were immediately placed on ice, and plasma was separated by centrifugation $(3,000 \times g, 15 \mathrm{~min})$ and frozen at $-20^{\circ} \mathrm{C}$ until analyses were performed.

Samples containing EDTA were used to determine cortisol, haptoglobin, PGFM, and $\mathrm{P}_{4}$; in addition, samples containing EDTA and acetylsalicylic acid were used for PGFM analysis. Plasma concentrations of cortisol and haptoglobin were determined by means of a RIA according to Thun et al. (1981) and a commercial ELISA (E-10HPT Bovine Haptoglobin ELISA kit, Immunology Consultants Laboratory, Portland, OR), respectively. Intra- and interassay coefficients of variation were 8.5 and $9.1 \%$, respectively, for cortisol, and $<10 \%$ for both assays for haptoglobin. The lower detection limit for cortisol was $0.83 \mathrm{nmol} / \mathrm{L}$ and that for haptoglobin was $6.26 \mathrm{ng} / \mathrm{mL}$. Plasma concentrations of PGFM (13,14-dihydro-15-keto-prostaglandin $\mathrm{F}_{2 \alpha}$; Sigma Aldrich) were analyzed using an enzymeimmunoassay according to Mishra et al. (2003). Antiserum and PGFM-horseradish peroxidase conjugate were kindly provided by the Department of Physiology in Weihenstephan (Technical University Munich, Germany). Intra- and interassay coefficients of variation for PGFM were $\leq 7.5$ and $\leq 12.7 \%$, respectively, and the lower detection limit was $12 \mathrm{ng} / \mathrm{mL}$. Plasma $\mathrm{P}_{4}$ concentrations were measured with a commercial RIA (RIA kit IM1188, Immunotech s.r.o., Prag, Czech Republic), and intra- and interassay coefficients of variation were $\leq 6.5$ and $\leq 7.2 \%$, respectively. The lower detection limit for $\mathrm{P}_{4}$ was $0.03 \mathrm{ng} / \mathrm{mL}$.

Concentrations of cortisol, PGFM, and $\mathrm{P}_{4}$ were analyzed in all plasma samples, whereas determination of haptoglobin was restricted to d 0, 6, and 9 .

\section{Ultrasonography}

Transrectal ultrasonographic examinations of the uterus and ovaries were performed using a portable ultrasound device (GE LOGIQ e Premium BT11, General Electric Medical System, Solingen, Germany), equipped with a 4.0 to $12.0 \mathrm{MHz}$, linear-array transducer.

Endometrial thickness was measured in both uterine horns separately on 3 frozen cross-sectional uterine images that were obtained about $4 \mathrm{~cm}$ cranial to the bifurcation (using B-mode ultrasonography). For each uterine horn, the mean endometrial thickness of the 3 images was calculated and averaged to obtain a thickness value for each heifer (the latter was used for data analysis). Furthermore, 3 cross-sectional B-mode images with maximal areas were frozen and recorded for every detectable CL and for each ovarian follicle with a diameter of $>9 \mathrm{~mm}$. The total area of the CL was measured using computer-assisted image analysis software (PixelFlux Version 1.0, Chameleon Software, Leipzig, Germany). When a cavity was present within a CL, the cavity area was separately assessed and subtracted from the total area of the CL. The difference between the total area of the CL and its cavity was defined as area of luteal tissue (LTA). Furthermore, the number of follicular waves within each cycle was determined, and the total area of each dominant and preovulatory follicle was measured on the day of the largest follicular diameter (determined retrospectively) and on the last day before ovulation, respectively, using PixelFlux software. Maximum cross-sectional area of follicles was defined as follicular size. For each CL and follicle, mean 
values of measurements of the 3 recorded images were used for data analysis.

The second part of the ultrasonographic examination used Power Mode ultrasonography to assess luteal blood flow (LBF) and follicular blood flow (FBF). The transducer was positioned at the maximal diameter of the CL or follicle, and small adjustments in location (relative to the ovary) were made to achieve a maximal number of color pixels in the luteal parenchyma or follicular wall, before freezing and recording the image. The number of pixels with color was determined (PixelFlux software) as a semiquantitative assessment of LBF and FBF. For each structure in each heifer, 3 images were recorded, and the average was used for data analysis. To calculate the relative LBF, LBF was divided by LTA.

In heifers with an ovulation of 2 dominant follicles between $\mathrm{d} 0$ and 1 (double ovulation), and a subsequent development of $2 \mathrm{CL}$, the mean and sum were applied for follicular and luteal measurements, respectively, as suggested by Bollwein et al. (2002).

\section{Endometrial Cytology, RNA Extraction, and Quantitative Real-Time Reverse Transcriptase PCR}

Endometrial cells were collected by means of a modified cytobrush (Minitüb $\mathrm{GmbH} \&$ Co. KG), using a diameter-reduced thin-walled uterine infusion pipette (Minitüb $\mathrm{GmbH} \& \mathrm{Co}$. KG) with rounded front ends as the guiding tube. To avoid contamination of the uterus during sampling, the cytobrush was coated with a hygienic sheath (Minitüb GmbH \& Co. KG) that was pierced through immediately before entering the cervix. After the cytobrush had passed through the cervix, guided by transrectal manual assistance, a cell sample was collected from the uterine corpus.

After cell collection, the cytobrush was streaked immediately on an RNase-free object slide, air-dried, and afterward stained with Diff-Quick (Henry Schein, Melville, NY). According to a modified schedule of Prieto et al. (2012), the number of PMN was counted within 10 different, randomly chosen fields of view using light microscopy at $400 \times$ magnification, and a total of $>5$ PMN was considered a subclinical endometritis.

After streaking, the cell-bearing end of the cytobrush was transferred into a micro test tube (Eppendorf type, PP natural $1.5 \mathrm{~mL}$ plain) that was filled with $1 \mathrm{~mL}$ of RNAlater (Ambion, Applied Biosystems Inc., Austin, TX), and stored at $4^{\circ} \mathrm{C}$ until RNA extraction for the analysis of the proinflammatory cytokines $I L 1 \beta, I L 8$, and tumor necrosis factor $\alpha(\boldsymbol{T N F A})$, as well as the cytosolic PGE synthase ( $\boldsymbol{c P G E S}$. The latter was de- termined because $\mathrm{PGE}_{2}$ concentrations in uterine fluid were assumed to be related to the degree of endometritis, revealing higher levels in cows with severe than in those with mild inflammation (Mateus et al., 2003).

Cytobrushes were transferred into $1 \mathrm{~mL}$ ice-cold PBS buffer and centrifuged for $15 \mathrm{~min}$ at $4^{\circ} \mathrm{C}$ and $11,000 \times$ $g$. Then brushes were removed after scraping them at the tube wall. After another centrifugation (15 min, $\left.4^{\circ} \mathrm{C}, 11,000 \times g\right)$ the supernatant was removed and the pellet resuspended in $1 \mathrm{~mL}$ of TriFast (peqLab, Erlangen, Germany) following a total RNA extraction according to manufacturer's instructions.

Quantitative real-time PCR analysis was performed with the Sensimix DNA Kit (Quantace, Biolabo, Châtel St. Denis, Switzerland) on a Rotor-Gene 6000 (Corbett Research, Sydney, Australia). One reaction mixture contained $2 \mu \mathrm{L}$ of cDNA equivalent to $25 \mathrm{ng}$ of total RNA, $0.8 \mu \mathrm{L}$ of RNase-free water (Qiagen, Hilden, Germany), $1 \mu \mathrm{L}$ (5 pmol) of forward primer, $1 \mu \mathrm{L}(5$ pmol) of reverse primer, and $5.2 \mu \mathrm{L}$ of $2 \times$ SensiMix plus SYBR-Green $\left(1 \mathrm{~m} M \mathrm{MgCl}_{2}\right)$.

The following 3-step PCR program was used: initial denaturation for $10 \mathrm{~min}$ at $95^{\circ} \mathrm{C}$, followed by 40 cycles with denaturation for $15 \mathrm{~s}$ at $95^{\circ} \mathrm{C}, 30 \mathrm{~s}$ at primerspecific annealing temperature, and elongation for $20 \mathrm{~s}$ at $72^{\circ} \mathrm{C}$. Fluorescence was acquired at $72^{\circ} \mathrm{C}$ after each cycle, and a dissociation melt curve of the PCR product was determined at the end of each run to verify the specificity of the PCR reactions. The primers used to amplify specific fragments referring to selected regulated genes are shown in Table 1. Ubiquitin and GAPDH were used as housekeeping genes.

Cycle threshold (Ct) values were determined by the Rotor-Gene software version 1.7.75, and the relative mRNA expression was calculated by means of the comparative Ct method using the following equation (Schmittgen and Livak, 2008):

$$
\Delta \mathrm{Ct}=\mathrm{Ct} \text { target gene }-\mathrm{Ct} \text { endogenous control }
$$

(arithmetic mean of housekeeping genes).

\section{Corpus Luteum Biopsy, RNA Extraction, and Quantitative Real-Time Reverse Transcriptase PCR}

Prior to the collection of CL biopsy samples, caudal epidural anesthesia was provided to the heifers by incorporating 40 to $50 \mathrm{mg}$ of lidocaine hydrochloride (Lidocain 2\% Streuli; Streuli Pharma AG, Uznach, Switzerland) to reduce rectal contractions. Two samples (approximately $15 \times 1 \times 1 \mathrm{~mm}$ each) were obtained from the maximum diameter of the CL (including cells from the periphery and the center), using a semi-auto- 
INTRAUTERINE LIPOPOLYSACCHARIDE INDUCES LUTEOLYSIS

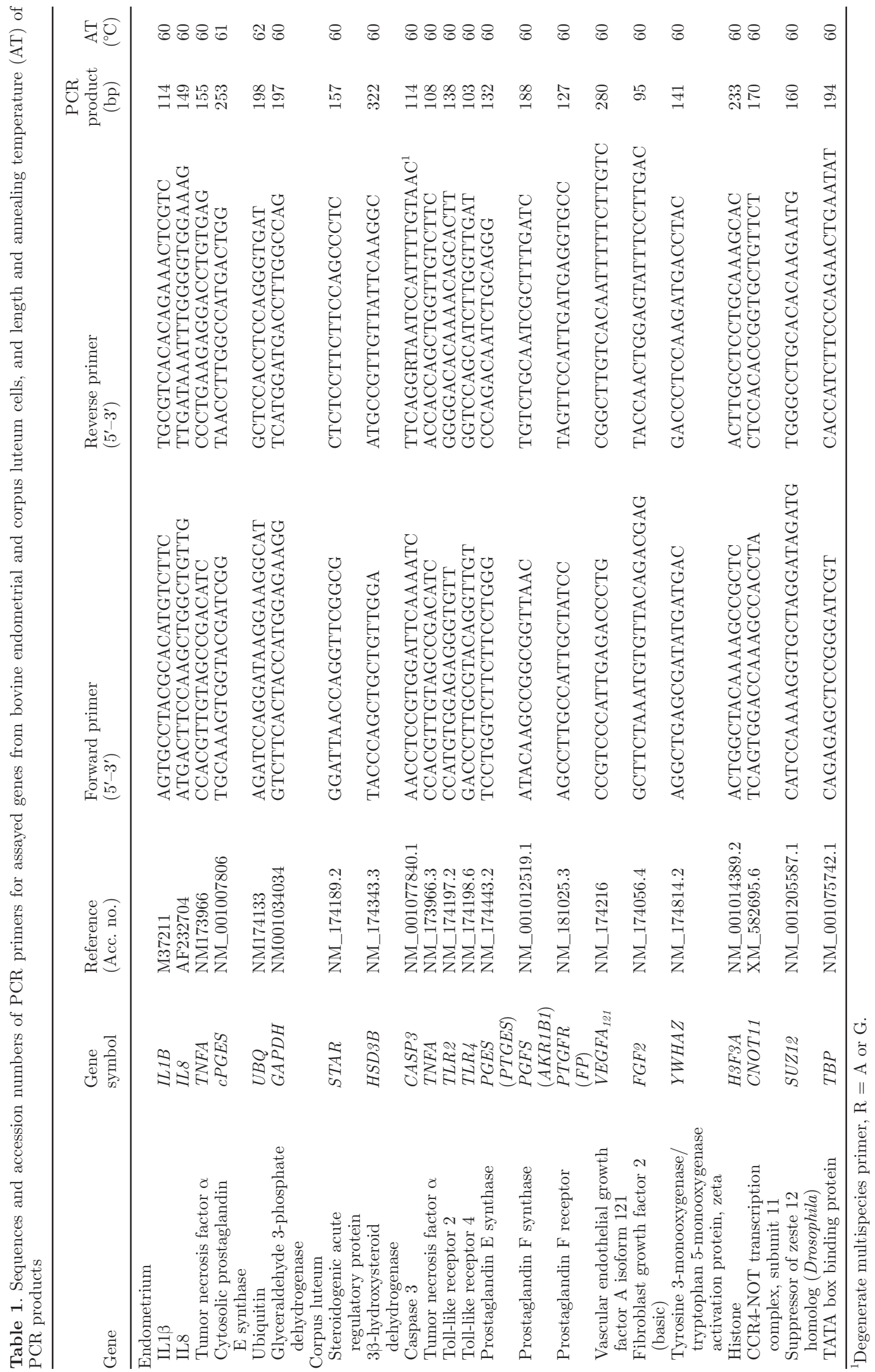


matic, high-speed biopsy needle (TEMNO Evolution; Fa. Walter, Baruth/Mark, Germany) that was rendered free of RNase (RNase-ExitusPlus; AppliChem, Darmstadt, Germany). For visual control, a portable ultrasound device (GE LOGIQ e Premium BT11), equipped with a $7.5-\mathrm{MHz}$ convex transducer, was used. The biopsy needle and the ultrasound transducer were guided transvaginally using a bearing system (type Hannover) and the CL was placed in front of the vaginal fornix by transrectal manual assistance. Tissue samples were immediately placed in sterile DNase- and RNase-free cryo tubes (Fa. Brand, Wertheim, Germany), frozen in liquid nitrogen and stored at $-80^{\circ} \mathrm{C}$ until expression analysis. This method allowed repeated biopsy sampling from a single CL without impairing its subsequent function (Tsai et al., 2001; Atli et al., 2012).

Luteal mRNA expression was determined for factors that are essential for steroidogenesis, namely steroidogenic acute regulatory protein $(\boldsymbol{S T A R})$ and $3 \beta$-hydroxysteroid dehydrogenase $(\boldsymbol{H S D} 3 \boldsymbol{B})$, the apoptosis-related enzyme caspase $3(\boldsymbol{C A S P} 3)$, TNFA, and toll-like receptor $(\boldsymbol{T L R})-2$ and $T L R$-4. Furthermore, luteal mRNA abundance of PGE- (PGES/PTGES) and PGF synthases (PGFS/AKR1B1) that catalyze the synthesis of the main luteotropic and luteolytic factors, PGF receptor $(\boldsymbol{P} \boldsymbol{T G F R} / \boldsymbol{F P})$, and the angiogenic factors, vascular endothelial growth factor A isoform 121 ( $\left.\boldsymbol{V E} \boldsymbol{E} \boldsymbol{F} \boldsymbol{A}_{121}\right)$ and fibroblast growth factor 2 (FGF2), was investigated.

Total RNA from luteal tissue samples was extracted using the miRNeasy Mini Kit (Qiagen). Homogenization of the tissues was achieved with the Qiagen TissueLyser II and 5-mm stainless steel beads (Qiagen). The RNA concentration and integrity were quantified using the NanoDrop 2000 (peqLab) and the Bioanalyzer 2100 (Agilent Technologies, Waldbronn, Germany), respectively. The RNA integrity numbers ranged from 6.7 to 10 (average 8.3). Five hundred nanograms of RNA was reverse transcribed using the M-MLV Reverse Transcriptase, RNase $\mathrm{H}$ Minus, Point Mutant (Promega, Madison, WI) as recently described (Pistek et al., 2013).

Luteal mRNA expression was determined in a 2-step quantitative real-time PCR using the CFX384 Real-Time PCR Detection System (Bio-Rad, Munich, Germany) and the SsoFast EvaGreen Supermix (BioRad). The quantitative real-time PCR was performed in a reaction volume of $10 \mu \mathrm{L}$, consisting of $5 \mu \mathrm{L}$ of EvaGreen Mix, $0.4 \mu \mathrm{L}$ of each primer $(10 \mu M), 0.07$ $\mu \mathrm{L}$ of VisiBlue (TATAA Biocenter, Göteborg, Sweden), $3.13 \mu \mathrm{L}$ of water, and $1 \mu \mathrm{L}$ of cDNA. The primers used to amplify specific fragments referring to selected regulated genes are shown in Table 1. The primer-specific annealing temperatures are outlined. The cycle number $\left(\mathbf{C}_{\mathbf{q}}\right)$ required to achieve a definite SYBR Green fluorescence signal was calculated by the regression method (Bio-Rad CFX Manager 3.1). The $\mathrm{C}_{\mathrm{q}}$ was inversely correlated with the logarithm of the initial template concentration. The $\mathrm{C}_{\mathrm{q}}$ determined for the target genes were normalized against the geometrical mean of the 5 reference genes YWHAZ, H3F3A, CNOT11, SUZ12, and $\operatorname{TBP}\left(\boldsymbol{\Delta} \mathbf{C}_{\mathbf{q}}\right)$. To avoid negative digits while allowing the estimation of a comparison between 2 genes, data were presented as means \pm SEM added to an arbitrary value of $10\left(\Delta \mathrm{C}_{\mathrm{q}}\right)$. Thus, a high $\Delta \mathrm{C}_{\mathrm{q}}$ proportionally resembled high transcript abundance (Livak and Schmittgen, 2001). In case of 2 CL due to double ovulation, the average $\Delta \mathrm{C}_{\mathrm{q}}$ of both $\mathrm{CL}$ was used for data analysis.

\section{Statistical Analyses}

Data from 4 estrous cycles [control (CON) cycles at the start $(\mathrm{n}=7)$ and end $(\mathrm{n}=8)$ of the study, PBS $(\mathrm{n}=7)$, and LPS $(\mathrm{n}=8)$ cycles] and from the first $9 \mathrm{~d}$ of the NLPS cycle $(\mathrm{n}=6)$ were used for data analysis. In 3 out of $15 \mathrm{CON}$ cycles at the start $(\mathrm{n}=1$; enteritis) and at the end of the study $(\mathrm{n}=2$; tracheobronchitis and vaginocervicitis), data from the onset of the inflammatory disease until the end of the cycle had to be excluded, and the heifers were not used for further experiments until full recovery. Data collection of one CON cycle at the end of the study could not be completed due to organizational reasons.

At the start of the study, a CON cycle was performed in the heifers to exclude any carry-over effect of the subsequent PBS and LPS treatments. To consider animal adaptation and growing, a second CON cycle was performed at the end of the study, and mean values from both CON cycles were used for data analysis.

Heifers of the LPS cycle showed premature luteolysis. For this reason, endometrial cells and luteal tissue were solely collected on d 0 (only endometrium) and 6, and LPS treatment was canceled if ovulation had occurred. In all heifers of the LPS group that ovulated $(n=6)$, cytology and biopsy were repeated on d 9 of the NLPS cycle.

Estrous cycle length varied among heifers and ranged from 18 to $26 \mathrm{~d}$ in CON and PBS cycles, and from 7 to $10 \mathrm{~d}$ in LPS cycles. To facilitate comparability, data of CON and PBS cycles were normalized to an average cycle length of $18 \mathrm{~d}$. Therefore, d 0 to 12 were maintained, and 2 and $0 \mathrm{~d}$ before the subsequent ovulation were used to characterize the remaining cycle. Examination days between $\mathrm{d} 12$ and $2 \mathrm{~d}$ before subsequent ovulation were excluded from data analysis. Data from the LPS 
cycles were normalized to an average cycle length of 9 $\mathrm{d}$ by maintaining the first $6 \mathrm{~d}$ of the cycle and the last 1 to $3 \mathrm{~d}$ before ovulation. In heifers without ovulation during the LPS cycle, the first $9 \mathrm{~d}$ of the cycle were used for data analysis.

For plasma PGFM concentrations below the lower detection limit, $11 \mathrm{ng} / \mathrm{mL}$ was used as an arbitrary value to allow statistical analysis. No significant difference was found between plasma with and without the acetylsalicylic acid additive for measurement of PGFM (unpublished data); therefore, means of both measurements at each time of the analysis were used.

Statistical analyses were conducted using the Statistical Analysis System version 9.3 (SAS Institute Inc., Cary, NC). The distribution of the data was tested for normality visually (PROC CHART) and by means of the Shapiro-Wilk test (PROC UNIVARIATE). For normal data of quantitative variables a repeated measures ANOVA (PROC GLM) was performed. Significant results were further evaluated using a Student's $t$-test (PROC MEANS) for dependent pairwise comparisons between the CON, PBS, LPS, and NLPS cycles. For nonnormal data of quantitative variables, a CochranMantel-Haenszel test based on rank scores was applied as equivalent to Friedman's 2-way ANOVA for repeated measures (PROC FREQ). Significant results were further evaluated with Wilcoxon's signed rank test (PROC UNIVARIATE) for dependent pairwise comparisons between cycles. Data were presented as mean \pm SEM or median, depending on the distribution of the data, and differences were considered significant at $P \leq 0.05$.

\section{RESULTS}

\section{Estrous Cycle Length and Endometrial Thickness, Cytology, and mRNA Expression}

The mean $( \pm \mathrm{SEM})$ interval between 2 ovulations did not differ between PBS $(21.7 \pm 1.0 \mathrm{~d})$ and $\mathrm{CON}$ cycles $(20.8 \pm 0.7 \mathrm{~d})$, but was shorter in the LPS cycle $(8.5$ $\pm 0.4 \mathrm{~d} ; \mathrm{n}=6)$ compared with the CON $(P<0.0001)$ and PBS cycles $(P=0.0003)$. However, in 2 heifers LPS challenge induced luteolysis without ovulation, despite the presence of follicles $>12 \mathrm{~mm}$.

Endometrial thickness was increased $(P<0.05)$ in the LPS compared with the CON cycle on $\mathrm{d} 2,6,8$, and 9 (Figure 1). Furthermore, endometrium was thicker $(P$ $<0.05)$ on $\mathrm{d} 6$ and 12 in the PBS and on $\mathrm{d} 1$ in the NLPS cycle compared with the CON cycle (Figure 1). Mean endometrial thickness during the whole estrous cycle was elevated $(P=0.02)$ in the PBS $(7.7 \pm 0.1$ $\mathrm{mm})$ compared with the CON cycle $(7.2 \pm 0.1 \mathrm{~mm})$.
Subclinical endometritis was diagnosed after LPS and PBS treatments in all heifers, whereas no increase of PMN was observed in CON cycles. The endometrial mRNA abundance of IL1B, IL8, TNFA, and $c P G E S$ did not differ on d 0 between LPS, PBS, and CON cycles (Figure 2). On d 6, mRNA expression of $I L 1 B$, $I L 8$, and TNFA was higher in LPS $(P \leq 0.009)$ and PBS cycles $(P \leq 0.02)$ compared with the CON cycle, whereas those of $c P G E S$ were similar between groups (Figure 2).

\section{Vital Parameters and Plasma Concentrations of Cortisol, Haptoglobin, and PGF ${ }_{2 \alpha}$ Metabolites}

During the whole estrous cycle, rectal temperature and cardiac and respiratory frequencies were not different in LPS and PBS cycles compared with the CON cycle, in which physiologic values of $38.5 \pm 0.01^{\circ} \mathrm{C}, 37.0$ \pm 1.8 breaths $/ \mathrm{min}$, and $84.0 \pm 2.1$ heartbeats $/ \mathrm{min}$ have been observed.

Mean plasma cortisol and haptoglobin concentrations of the LPS and the PBS cycle did not differ from the CON cycle that revealed average cortisol and haptoglobin concentrations of $4.2 \pm 0.5 \mathrm{nmol} / \mathrm{L}$ and $947.9 \pm$ $135.3 \mathrm{ng} / \mathrm{mL}$, respectively.

Plasma PGFM concentrations on d 1 to 9 (i.e., the treatment period) did not differ significantly between LPS, PBS, NLPS, and CON cycles (Figure 3A). Mean PGFM concentrations during this period were higher $(P=0.03)$ in the LPS cycle but similar in the PBS and NLPS cycles compared with the CON cycle (Figure $3 \mathrm{~B})$.

\section{Plasma Progesterone Concentrations and Luteal Size and Blood Flow}

Plasma $\mathrm{P}_{4}$ concentrations were decreased $(P<0.01)$ on $\mathrm{d} 6,8$, and 9 in the LPS cycle compared with the CON cycle (Figure 4A) but did not differ between the PBS and the CON cycle. Furthermore, lower $\mathrm{P}_{4}$ concentrations were observed on $\mathrm{d} 2(P=0.003)$ and $4(P$ $=0.009)$ of the NLPS compared with the CON cycle (Figure 4A).

The LTA was decreased in the LPS and increased in the PBS cycle on d 8 and 9 compared with the CON cycle (each $P<0.05$; Figure 4B) but did not differ between the NLPS and the CON cycle. Double ovulation and development of $2 \mathrm{CL}$ occurred during the CON and the PBS cycle in one heifer each.

Luteal blood flow was decreased $(P<0.01)$ in the LPS cycle on d 6,8 , and 9 , and increased $(P=0.05)$ in the PBS cycle on d 9 compared with the CON cycle 


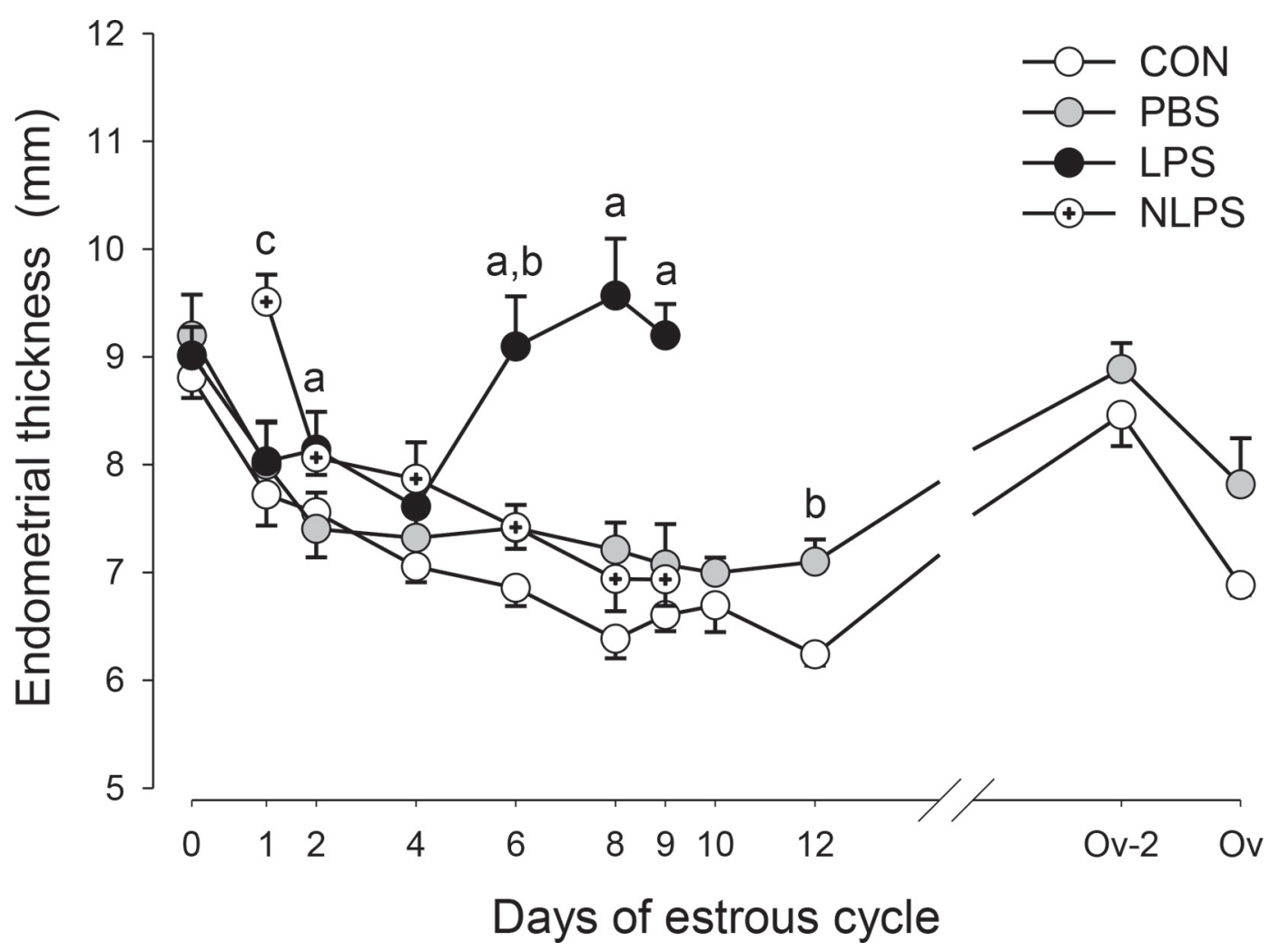

Figure 1. Changes (means \pm SEM) in endometrial thickness of 8 heifers during untreated estrous cycles (CON), cycles with intrauterine PBS or LPS treatments at 6 -h intervals between $\mathrm{d} 0$ and $9(\mathrm{~d} 1=$ ovulation, Ov), and the first $9 \mathrm{~d}$ of the next cycle after the LPS cycle (NLPS). ${ }^{\mathrm{a}-\mathrm{c}}$ Difference $(P \leq 0.05)$ between LPS and CON $\left({ }^{\mathrm{a}}\right)$, PBS and CON $\left({ }^{\mathrm{b}}\right)$, and NLPS and CON cycles $\left({ }^{\mathrm{c}}\right)$ at times indicated.

(Figure 4C). Relative LBF was higher in the LPS compared with the CON cycle on d $1(0.30 \pm 0.04$ vs. 0.18 $\pm 0.03 ; P=0.003)$, and lower on $\mathrm{d} 8(0.04 \pm 0.01$ vs. $0.15 \pm 0.02 ; P=0.02)$ and $9(0.03 \pm 0.01$ vs. $0.14 \pm$ $0.02 ; P=0.002)$. Neither the LBF nor the relative LBF differed between the NLPS and the CON cycle.

\section{Luteal mRNA Expression}

Changes in mRNA expression of all investigated parameters are shown in Figure 5. Luteal mRNA expression of STAR and HSD $3 B$ was decreased $(P<0.01)$ in the LPS compared with the CON cycle, whereas the expression of $C A S P 3$ mRNA was increased $(P=$ 0.02 ) in the LPS compared with the CON cycle (Figure $5 \mathrm{~A})$. No difference was found in the mRNA expression of TNFA and TLR2 in PBS, LPS, and NLPS cycles compared with the CON cycle, but mRNA abundance of TLR 4 was higher $(P=0.04)$ in the LPS compared with the CON cycle (Figure 5B). Luteal expression of $P G E S$ mRNA was increased $(P=0.05)$ in the LPS cycle compared with the CON cycle, whereas mRNA abundance of $P G F S$ was not different in PBS, LPS, and NLPS cycles compared with the CON cycle (Fig- ure $5 \mathrm{C})$. Furthermore, expression of PTGFR mRNA was reduced $(P=0.02)$ in the LPS compared with the CON cycle (Figure 5C). Luteal mRNA expression of $V E G F A_{121}$ was decreased $(P=0.0005)$ in the LPS compared with the CON cycle, whereas FGF2 mRNA did not differ between any of the cycles (Figure 5D).

\section{Number of Follicular Waves and Follicular Size and Blood Flow}

The number of follicular waves did not differ between the PBS $(2.7 \pm 0.5)$ and the CON cycle $(2.4 \pm 0.2)$ but was smaller in the LPS cycle (one follicular wave in all heifers) compared with the CON $(P=0.008)$ and the PBS cycle $(P=0.002)$. The dominant follicle of the first wave was bigger in the NLPS cycle compared with the CON $(P=0.001)$ and the PBS cycle $(P=0.01$; Table 2). The size of the preovulatory follicle (of the first wave) in the LPS cycle did not differ from the size of the dominant follicle of the first wave, or from the size of the preovulatory follicle of the second wave in the CON and the PBS cycle. No differences were found in FBF of the dominant and the preovulatory follicle between cycles. 


\section{DISCUSSION}

The diagnosis of subclinical endometritis in both the LPS and the PBS cycle suggests that the responsible for uterine inflammation is the repeated transcervical passage, rather than the applied reagent. Likewise, cervical dilation can induce endometritis in mares (Handler et al., 2006). Moreover, it is possible that PBS has irritated the endometrium and induced inflammation. In consistence with cytological diagnosis of endometritis, mRNA abundance of proinflammatory cytokines $I L 1 B$, $I L 8$, and TNFA in endometrial cells was increased in the LPS and the PBS cycle. Increased endometrial expression of these cytokines during subclinical endometritis has been previously reported (Ghasemi et al., 2012; Swangchan-Uthai et al., 2012), and IL8, in particular, was associated with a recruitment of PMN to the site of infection (Harada et al., 1994). In a previous study (Gabler et al., 2009), the mRNA expression of $c P G E S$ was decreased in cows with subclinical endometritis; however, in our study, the expression of $c P G E S$ mRNA did not differ between LPS, PBS, and CON cycles.

Repeated intrauterine LPS applications induced premature luteolysis. Consequently, the LPS cycle was shorter compared with the PBS and the CON cycle. In contrast, estrous cycle length did not differ after a single intrauterine infusion of LPS $(5 \mu \mathrm{g} / \mathrm{kg}$ of BW) during the mid-luteal phase (Gilbert et al., 1990), indicating that repeated intrauterine LPS applications are required to induce luteolysis. Consistently, a single intrauterine application of living E. coli, which is associated with a continuous release of LPS, tended to shorten estrous cycle length (Gilbert et al., 1990). Furthermore, in our study 2 heifers of the LPS cycle failed
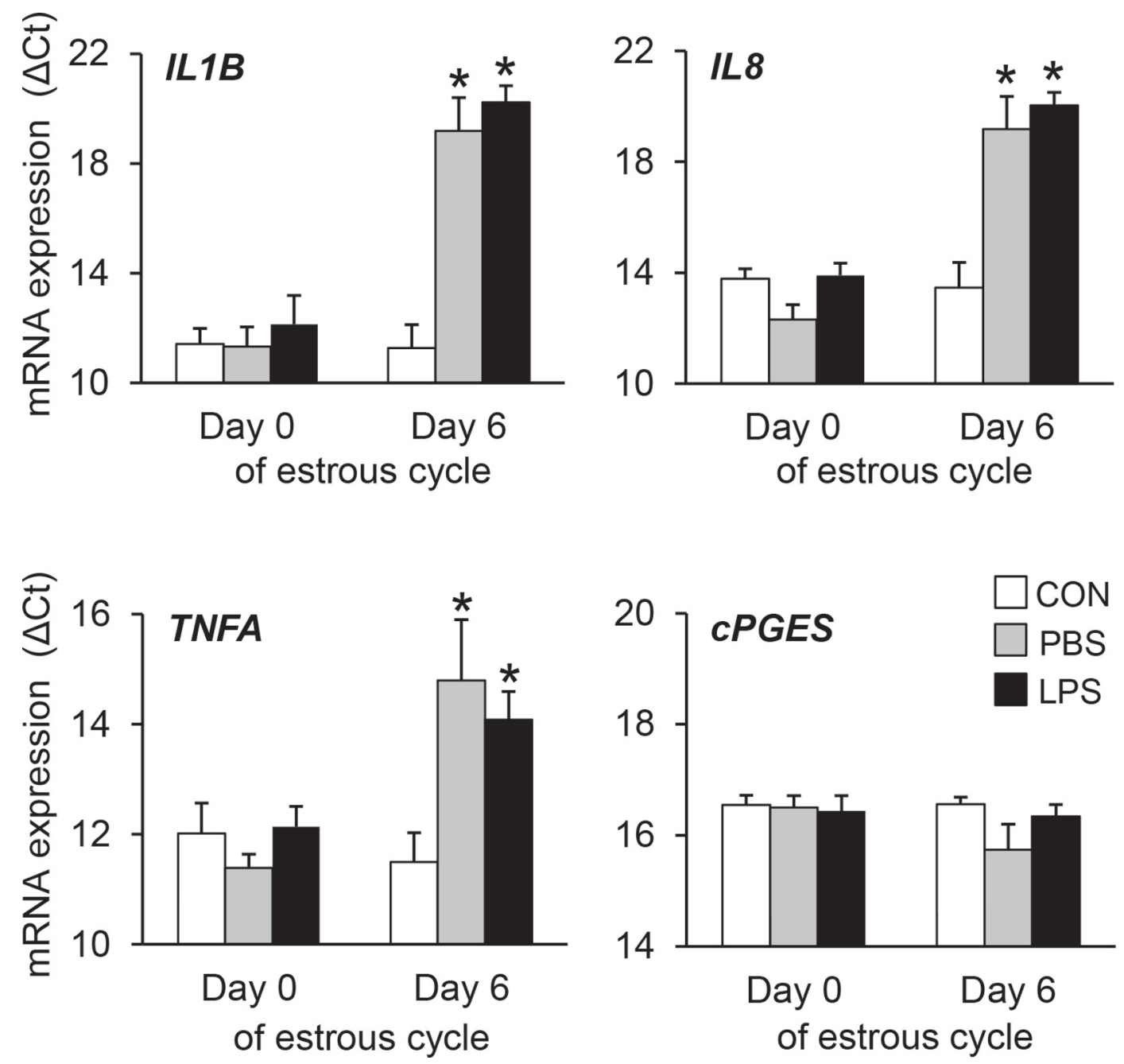

Figure 2. Endometrial mRNA expressions (means \pm SEM) of $I L 1 \beta$ (IL1B), IL8, tumor necrosis factor $\alpha$ (TNFA), and cytosolic prostaglandin E synthase $(c P G E S)$ in 8 heifers on d 0 and 6 (d 1 = ovulation) of untreated estrous cycles $(\mathrm{CON})$, and cycles with intrauterine PBS or LPS treatments at 6 -h intervals between d 0 and $9 .{ }^{*}$ Difference $(P \leq 0.05)$ between the indicated cycle and the CON cycle at the respective time. 


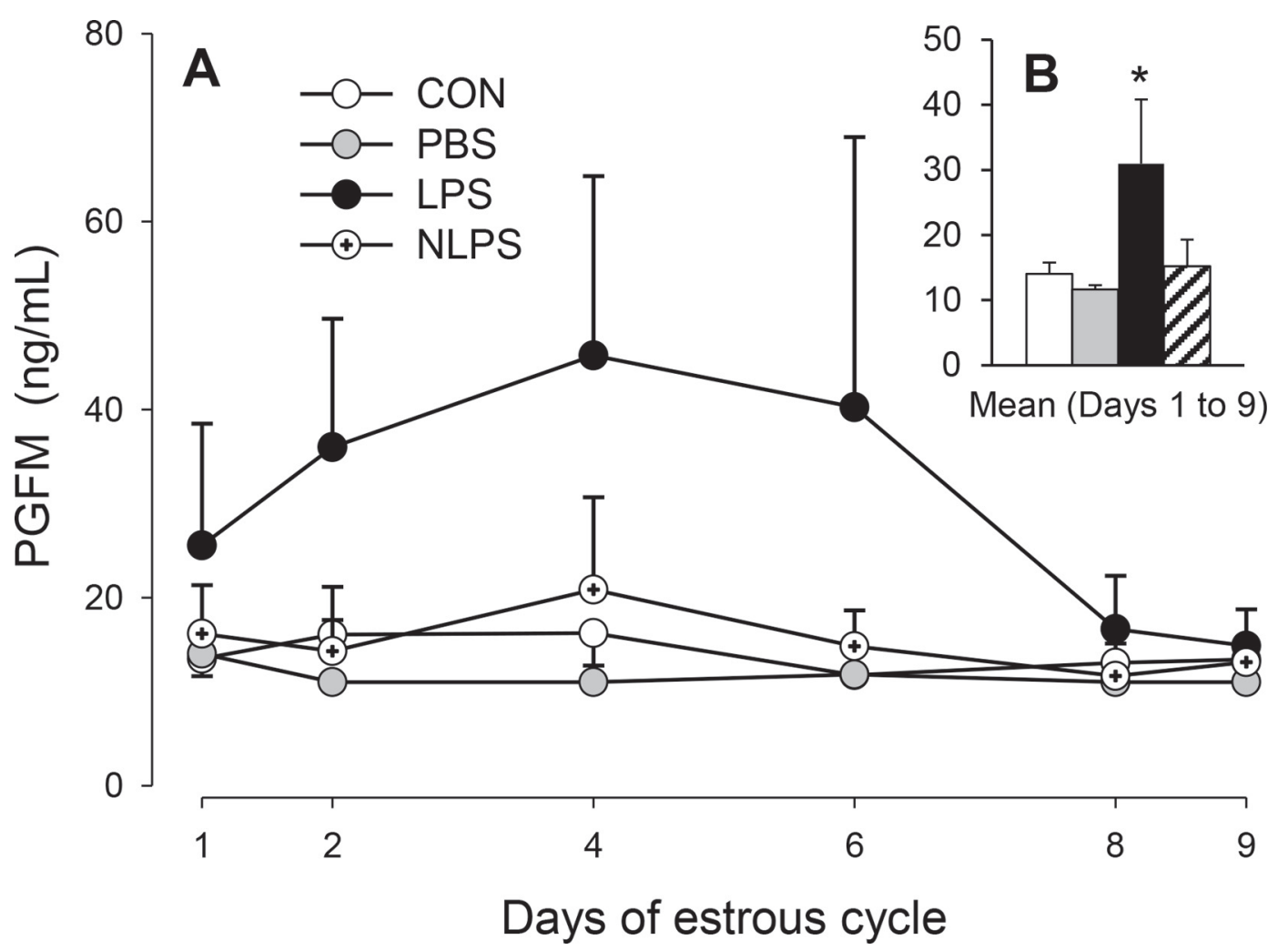

Figure 3. Plasma PGFM concentrations (means \pm SEM) of 8 heifers on a single-day basis (A) and as an average (B) of the first $9 \mathrm{~d}$ during untreated estrous cycles (CON; white column), cycles with intrauterine PBS (gray column), or LPS (black column) treatments at 6-h intervals between $\mathrm{d} 0$ and 9 (d 1 = ovulation), and the next cycle after the LPS cycle (NLPS; black-striped column). $*$ Difference $(P \leq 0.05)$ between the indicated cycle and the CON cycle.

to ovulate despite luteolysis. This finding is consistent with the failure to ovulate after $\mathrm{PGF}_{2 \alpha}$-induced luteolysis in 3 out of 8 cows after repeated intrauterine LPS challenge (Williams et al., 2008).

Preterm increase in endometrial thickness during the LPS cycle was due to premature luteolysis and the induction of estrus, which is associated with lower plasma $\mathrm{P}_{4}$ and higher estradiol concentrations (Souza et al., 2011). The thicker endometrium on $\mathrm{d} 1$ in the NLPS cycle compared with the CON cycle was most likely induced by retained inflammatory edema of the endometrium as a carry-over effect from the preceding cycle. Moreover, the reason could have been the lower plasma $\mathrm{P}_{4}$ levels during the first days of the NLPS cycle that decrease the estradiol: $\mathrm{P}_{4}$ ratio according to Souza et al. (2011). Inflammatory edema of the endometrium was probably the reason for the increased endometrial thickness in the PBS compared with the CON cycle.

Rectal temperature, and cardiac and respiratory frequencies did not change in heifers during intrauterine LPS challenge. In contrast, these parameters increased after intravenous $(0.5 \mu \mathrm{g} / \mathrm{kg}$ of BW; Lavon et al., 2008; Herzog et al., 2012) and intramammary LPS applica- tion $(10 \mu \mathrm{g} / \mathrm{cow}$; Lavon et al., 2008), indicating that the endometrium is less sensitive to local LPS challenge with regard to the induction of a systemic immune response. Moreover, plasma concentrations of cortisol, which is a good index of stress in cattle (Mudron et al., 2007; Mosher et al., 2013), and haptoglobin, an acute phase protein that is released during the innate immune response to inflammation (Murata et al., 2004), were similar in the LPS and the CON cycle. Because an acute phase response is characterized by pyrexia (Ma et al., 2011), unchanged haptoglobin levels were consistent with physiological rectal temperatures.

The average plasma PGFM concentration during $\mathrm{d}$ 1 to 9 was higher in the LPS compared with the CON cycle. We infer that the irritation of the endometrium by LPS induces a uterine release of $\mathrm{PGF}_{2 \alpha}$ to the circulation and consequently an elevation of plasma PGFM levels. Increased PGFM levels were also induced by a single intrauterine infusion of LPS $(5 \mu \mathrm{g} / \mathrm{kg}$ of BW) in postpartum (Peter et al., 1990) but not in cycling cows (Gilbert et al., 1990), most likely due to the presence of living $E$. coli that continuously release LPS in postpartum cows (Sheldon et al., 2002; Magata et al., 

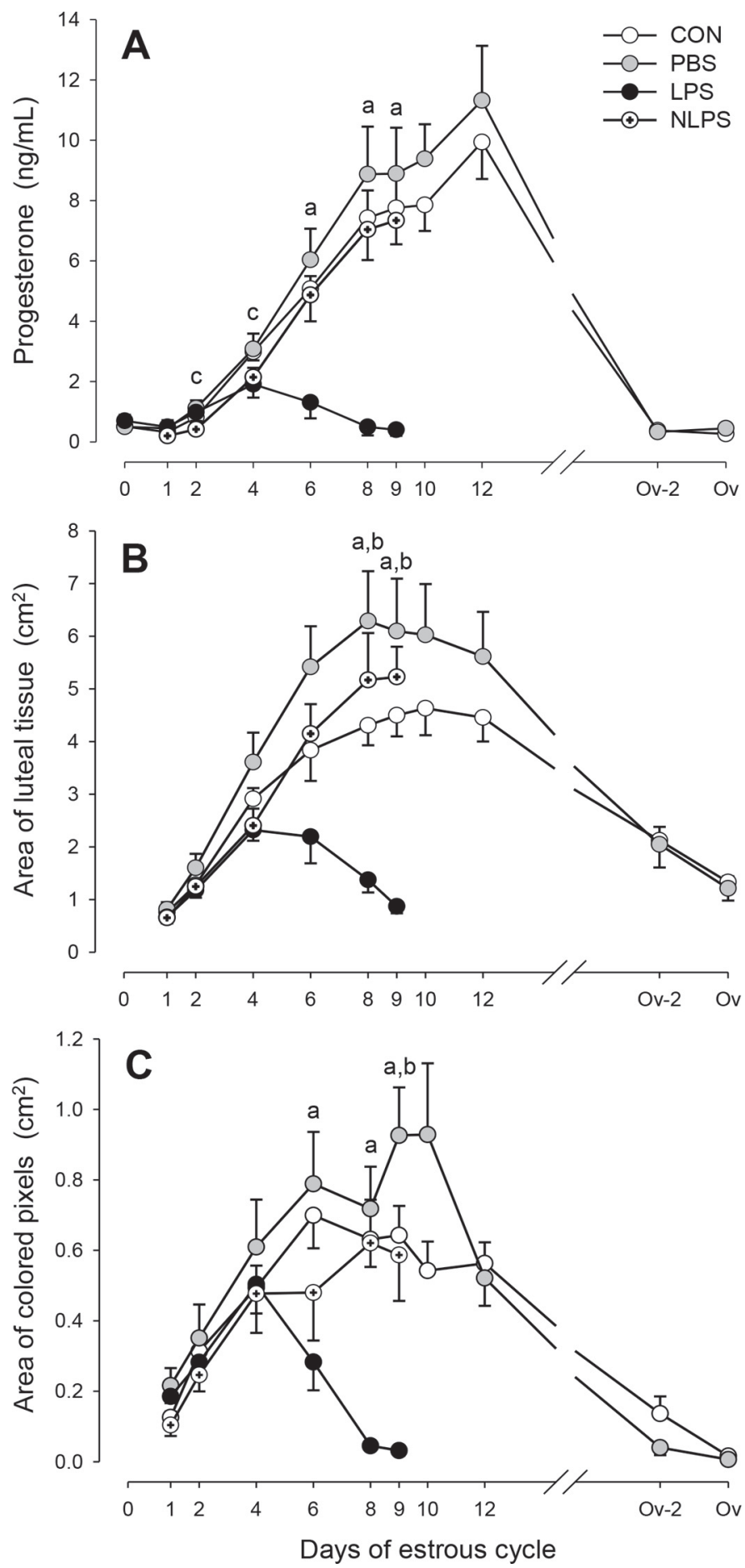

Figure 4. Changes (means \pm SEM) in plasma progesterone concentrations (A), the area of luteal tissue (B), and the area of colored pixels expressing luteal blood flow (C) of 8 heifers during untreated estrous cycles $(\mathrm{CON})$, cycles with intrauterine PBS or LPS treatments at 6 -h intervals between $\mathrm{d} 0$ and 9 (d 1 = ovulation, $\mathrm{Ov}$ ), and the first $9 \mathrm{~d}$ of the next cycle after the LPS cycle (NLPS). ${ }^{\mathrm{a}-\mathrm{c}}$ Difference $(P \leq$ 0.05 ) between LPS and CON $\left({ }^{a}\right)$, PBS and CON $\left({ }^{b}\right)$, and NLPS and CON cycles $\left({ }^{\mathrm{C}}\right)$ at times indicated.
2015). Consistently, in severe metritis cases high concentrations of LPS in the uterine fluid and of PGFM in plasma have been documented (Mateus et al., 2003).

Plasma $\mathrm{P}_{4}$ concentrations were decreased in the LPS compared with the CON cycle from d 6 on, indicating a premature functional luteolysis. In another study with repeated intrauterine LPS infusions (Williams et al., 2008), $\mathrm{P}_{4}$ levels also reduced, whereas a single intrauterine LPS infusion failed to change $\mathrm{P}_{4}$ concentrations (Gilbert et al., 1990). In contrast, a single intravenous application of LPS decreased plasma $\mathrm{P}_{4}$ levels (Herzog et al., 2012). Because studies with decreased (Williams et al., 2008; Herzog et al., 2012) and unchanged (Gilbert et al., 1990) $\mathrm{P}_{4}$ concentrations reported increased and unchanged PGFM levels, respectively, alterations in luteal function were determined by $\mathrm{PGF}_{2 \alpha}$ release. However, direct effects of LPS on the CL cannot be excluded because a significant decrease in $\mathrm{P}_{4}$ secretion was also observed after exposition of luteal cells to LPS in vitro (Mishra and Dhali, 2007). Furthermore, LPS was suspected to directly reduce plasma $\mathrm{P}_{4}$ levels on $\mathrm{d}$ 2 to 4 in the NLPS cycle (i.e., when the CL is refractory to $\left.\mathrm{PGF}_{2 \alpha}\right)$.

The reduction in luteal size, which parallels the decreased $\mathrm{P}_{4}$ concentrations from $\mathrm{d} 8$ on, indicates a structural luteolysis. Although the effect of repeated intrauterine LPS infusions on bovine luteal development has not been reported until now, prolonged rather than shortened luteal phases have been hypothesized (Herath et al., 2009). In contrast to the complete luteolysis in our study, a single intravenous LPS challenge induced only a partial luteolysis, which was followed by a recovery of the CL (Herzog et al., 2012). Luteal blood flow was significantly decreased at times of reduced $\mathrm{P}_{4}$ concentrations in the LPS compared with the CON cycle, indicating a close association between perfusion and function of the CL. A reduced LBF was also reported after a single intravenous LPS challenge (Herzog et al., 2012) and after $\mathrm{PGF}_{2 \alpha}$-induced luteolysis (Trevisol et al., 2015). Increased luteal size and blood flow in the PBS compared with the CON cycle were attributed to the use of the sum for LTA and LBF measurements in cycles with double ovulations (according to Bollwein et al., 2002), and this difference was not apparent when the mean was used instead.

Luteal mRNA expression of $S T A R$ and $H S D 3 B$ was lower in the LPS cycle compared with the CON cycle, which is consistent with the reduced mRNA abundance of these steroidogenic factors after intravenous LPS challenge (Herzog et al., 2012) and $\mathrm{PGF}_{2 \alpha}$-induced luteolysis (Tsai et al., 2001; Shirasuna et al., 2010; Atli et al., 2012). Because STAR and HSD3B are key enzymes for the synthesis of $\mathrm{P}_{4}$ (Stocco and Clark, 

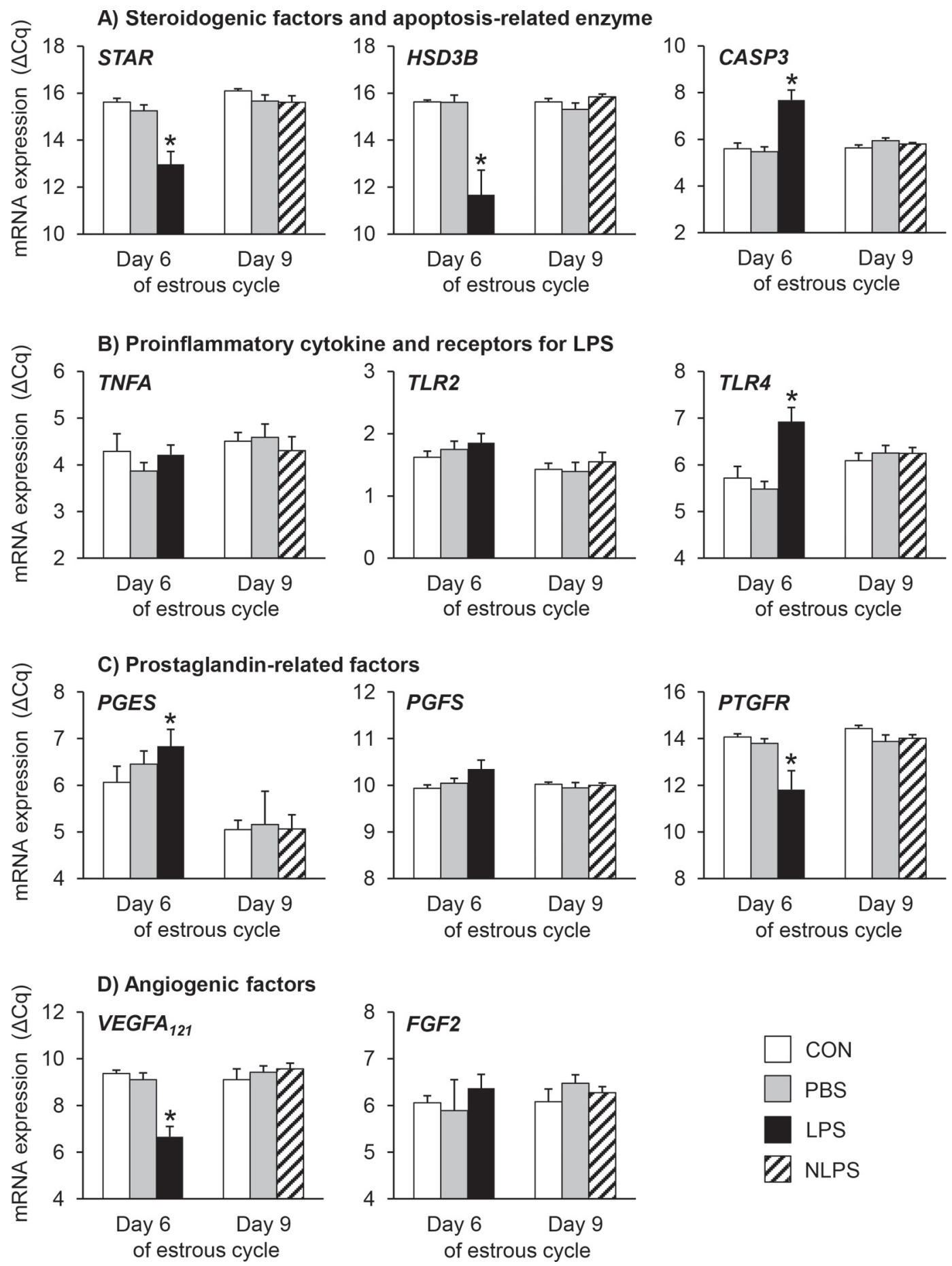

Figure 5. Luteal mRNA expressions (means \pm SEM) of steroidogenic acute regulatory protein $(S T A R)$, 3- $\beta$-hydroxysteroid dehydrogenase $(H S D 3 B)$, caspase $3(C A S P 3)$, tumor necrosis factor a $(T N F A)$, toll-like receptor $(T L R)$ 2. TLR , prostaglandin E synthase $(P G E S)$, PGFS, prostaglandin F receptor $(P T G F R)$, vascular endothelial growth factor A isoform $121\left(V E G F A_{121}\right)$, and fibroblast growth factor (FGF2) in 8 heifers on d 6 and 9 (d 1 = ovulation) of untreated estrous cycles $(\mathrm{CON})$, cycles with intrauterine PBS or LPS treatments at 6-h intervals between $\mathrm{d} 0$ and 9 , and the next cycle after the LPS cycle (NLPS). ${ }^{*}$ Difference $(P \leq 0.05)$ between the indicated cycle and the CON cycle at the respective time. 
Table 2. Mean ( \pm SEM) size (FS) and blood flow (FBF) of the dominant follicle of the first follicular wave and the preovulatory follicle with maximal diameters before regression and ovulation, respectively, in 8 heifers during untreated estrous cycles $(\mathrm{CON})$, cycles with intrauterine PBS or LPS treatments at 6-h intervals between $\mathrm{d} 0$ and 9 (d 1 = ovulation), and the first $9 \mathrm{~d}$ of the next cycle after the LPS cycle (NLPS)

\begin{tabular}{lccccc}
\hline & \multicolumn{2}{c}{ Dominant follicle $(1$ st wave $)$} & & \multicolumn{2}{c}{ Preovulatory follicle } \\
\cline { 2 - 3 } \cline { 5 - 6 } Item & FS $\left(\mathrm{cm}^{2}\right)$ & FBF $\left(\mathrm{mm}^{2}\right)$ & & FS $\left(\mathrm{cm}^{2}\right)$ & FBF $\left(\mathrm{mm}^{2}\right)$ \\
\hline CON & $1.75 \pm 0.13^{\mathrm{a}}$ & $2.95 \pm 0.55$ & & $1.82 \pm 0.12$ & $3.71 \pm 0.65$ \\
PBS & $1.92 \pm 0.16^{\mathrm{a}}$ & $2.19 \pm 0.93$ & & $1.73 \pm 0.14$ & $4.83 \pm 1.25$ \\
LPS & $2.14 \pm 0.22^{\mathrm{ab}}$ & $4.98 \pm 1.48$ & & $2.14 \pm 0.22$ & $4.98 \pm 1.48$ \\
NLPS & $2.06 \pm 0.19^{\mathrm{b}}$ & $1.47 \pm 0.76$ & & - & - \\
\hline
\end{tabular}

${ }^{\mathrm{a}, \mathrm{b}}$ Values within columns with different superscripts differ $(P \leq 0.05)$.

1996; Niswender, 2002), their reduced luteal expression confirms the reduction in $\mathrm{P}_{4}$ concentrations. Expression of $C A S P 3$ mRNA was increased in the LPS compared with the CON cycle, in consistency with the alterations noticed after intravenous LPS challenge (Herzog et al., 2012) and $\mathrm{PGF}_{2 \alpha}$-induced luteolysis (Kliem et al., 2009). Elevated CASP3, which is the key feature of induced apoptosis (Carambula et al., 2002), was associated with structural luteolysis.

There was no difference in the mRNA expression of TNFA between the LPS and the CON cycle. Following $\mathrm{PGF}_{2 \alpha}$-induced luteolysis, TNFA increased significantly after $15 \mathrm{~min}$ but returned to initial values within 12 h (Nitta et al., 2013). It is possible that the reason we could not detect the increase in luteal TNFA was the variable time (relative to biopsy) of LPS-induced luteolysis.

Expression of TLR4 mRNA was significantly higher in the LPS compared with the CON cycle but TLR2 mRNA did not differ between cycles. Whereas TLR4 selectively binds LPS (Chow et al., 1999; Takeuchi and Akira, 2010), TLR2 recognizes different components of gram-positive bacteria, mycoplasma, and fungi (Takeuchi et al., 1999; Takeuchi and Akira, 2010). Because TLR4 is essential for the binding of LPS to cells (Beutler, 2004), the increased luteal expression of TLR4 mRNA indicates that LPS from the uterus has reached the CL. In contrast, unspecific response to proinflammatory cytokines is reflected in increased mRNA abundance of TLR2 (Davanian et al., 2012).

Luteal mRNA expression of $P G E S$ was higher in the LPS compared with the CON cycle, whereas PGFS mRNA did not differ between cycles. However, luteolysis was not associated with increased PGES mRNA expression (Shirasuna et al., 2010). In contrast, luteal expression of $P G F S$ was increased after induced luteolysis during the mid-luteal phase (d 9 to 12; Shirasuna et al., 2010; Atli et al., 2012) but tended to be reduced during the early luteal phase (d 4; Shirasuna et al., 2010). Therefore, we assume that the absence of dif- ference in the present study was due to the sampling time on $\mathrm{d} 6$ (i.e., between the early and the mid-luteal phase). Expression of PTGFR mRNA was significantly decreased in the LPS compared with the CON cycle, which is consistent with the alterations observed in cows with regressing CL (Sakamoto et al., 1995; Shirasuna et al., 2012) and $\mathrm{PGF}_{2 \alpha}$-induced luteolysis (Levy et al., 2000; Tsai et al., 2001; Atli et al., 2012; Shirasuna et al., 2012).

The reduction in mRNA expression of $V E G F A_{121}$ in the LPS compared with the CON cycle was accompanied by a reduced LBF on the same day and was consistent with a decreased expression of VEGFA after $\mathrm{PGF}_{2 \alpha}$-induced luteolysis (Shirasuna et al., 2010; Atli et al., 2012). In contrast, FGF2 mRNA did not differ between the LPS and the CON group, possibly due to the time of sampling between the early and the mid-luteal phase. In a previous study, $\mathrm{PGF}_{2 \alpha}$-induced luteolysis during the early and the mid-luteal phase was associated with elevated and decreased expressions of FGF2 mRNA, respectively (Shirasuna et al., 2010).

In the LPS cycle, only one follicular wave was found compared with 2 or 3 waves in the CON and PBS cycles. Obviously, premature functional luteolysis that is characterized by a premature decrease in plasma $\mathrm{P}_{4}$ concentrations induced ovulation of the first wave. The maximum diameter of the dominant follicle of the first wave was increased in the NLPS cycle compared with the CON cycle. It is likely that the significantly lower $\mathrm{P}_{4}$ concentrations during the first days of the NLPS cycle were responsible for the increased follicular growth as maximum follicular diameter is increased in cows with low $\mathrm{P}_{4}$ levels (Cerri et al., 2011).

In conclusion, repeated intrauterine LPS infusions alter gene expression and induce premature lysis of the bovine CL. Luteolysis is most likely mediated by the LPS-induced endometrial release of $\mathrm{PGF}_{2 \alpha}$ (reflected by the increased plasma PGFM) but an additional direct effect of LPS via TLR4 on the bovine CL cannot be excluded. 


\section{ACKNOWLEDGMENTS}

The authors declare that there is no conflict of interest that could be perceived as prejudicing the impartiality of the research reported. This research did not receive any specific grant from any funding agency in the public, commercial, or not-for-profit sector. We acknowledge our colleagues at Veterinary Physiology, Vetsuisse Faculty University of Bern, and at Agroscope Liebefeld-Posieux, Switzerland: Y. Zbinden, M. Morel, and C. Philipona for laboratory work, and L. Eggerschwiler and P. Schärli for organization of the heifers and for assistance during collection of corpus luteum biopsies, respectively.

\section{REFERENCES}

Atli, M. O., R. W. Bender, V. Mehta, M. R. Bastos, W. Luo, C. M. Vezina, and M. C. Wiltbank. 2012. Patterns of gene expression in the bovine corpus luteum following repeated intrauterine infusions of low doses of prostaglandin F2alpha. Biol. Reprod. 86:130.

Battaglia, D. F., H. B. Krasa, V. Padmanabhan, C. Viguie, and F. J. Karsch. 2000. Endocrine alterations that underlie endotoxininduced disruption of the follicular phase in ewes. Biol. Reprod. 62:45-53.

Beutler, B. 2004. Inferences, questions and possibilities in Toll-like receptor signalling. Nature 430:257-263.

Bollwein, H., R. Mayer, F. Weber, and R. Stolla. 2002. Luteal blood flow during the estrous cycle in mares. Theriogenology 57:20432051.

Carambula, S. F., T. Matikainen, M. P. Lynch, R. A. Flavell, P. B. Goncalves, J. L. Tilly, and B. R. Rueda. 2002. Caspase-3 is a pivotal mediator of apoptosis during regression of the ovarian corpus luteum. Endocrinology 143:1495-1501.

Cerri, R. L., R. C. Chebel, F. Rivera, C. D. Narciso, R. A. Oliveira, W. W. Thatcher, and J. E. Santos. 2011. Concentration of progesterone during the development of the ovulatory follicle: I. Ovarian and embryonic responses. J. Dairy Sci. 94:3342-3351.

Cheong, S. H., D. V. Nydam, K. N. Galvao, B. M. Crosier, and R. O. Gilbert. 2011. Cow-level and herd-level risk factors for subclinical endometritis in lactating Holstein cows. J. Dairy Sci. 94:762-770.

Chow, J. C., D. W. Young, D. T. Golenbock, W. J. Christ, and F. Gusovsky. 1999. Toll-like receptor-4 mediates lipopolysaccharideinduced signal transduction. J. Biol. Chem. 274:10689-10692.

Davanian, H., T. Bage, J. Lindberg, J. Lundeberg, H. Q. Concha, M. Sallberg Chen, and T. Yucel-Lindberg. 2012. Signaling pathways involved in the regulation of TNFalpha-induced toll-like receptor 2 expression in human gingival fibroblasts. Cytokine 57:406-416.

Deguillaume, L., A. Geffre, L. Desquilbet, A. Dizien, S. Thoumire, C. Vorniere, F. Constant, R. Fournier, and S. Chastant-Maillard. 2012. Effect of endocervical inflammation on days to conception in dairy cows. J. Dairy Sci. 95:1776-1783.

Gabler, C., M. Drillich, C. Fischer, C. Holder, W. Heuwieser, and R. Einspanier. 2009. Endometrial expression of selected transcripts involved in prostaglandin synthesis in cows with endometritis. Theriogenology 71:993-1004.

Gautam, G., T. Nakao, M. Yusuf, and K. Koike. 2009. Prevalence of endometritis during the postpartum period and its impact on subsequent reproductive performance in two Japanese dairy herds. Anim. Reprod. Sci. 116:175-187.

Ghasemi, F., P. Gonzalez-Cano, P. J. Griebel, and C. Palmer. 2012. Proinflammatory cytokine gene expression in endometrial cytobrush samples harvested from cows with and without subclinical endometritis. Theriogenology 78:1538-1547.

Gilbert, R. O. 2011. The effects of endometritis on the establishment of pregnancy in cattle. Reprod. Fertil. Dev. 24:252-257.
Gilbert, R. O., W. T. Bosu, and A. T. Peter. 1990. The effect of Escherichia coli endotoxin on luteal function in Holstein heifers. Theriogenology 33:645-651.

Gilbert, R. O., S. T. Shin, C. L. Guard, H. N. Erb, and M. Frajblat. 2005. Prevalence of endometritis and its effects on reproductive performance of dairy cows. Theriogenology 64:1879-1888.

Ginther, O. J. 1974. Internal regulation of physiological processes through local venoarterial pathways: A review. J. Anim. Sci. 39:550-564.

Handler, J., D. Hoffmann, F. Weber, D. Schams, and C. Aurich. 2006. Oxytocin does not contribute to the effects of cervical dilation on progesterone secretion and embryonic development in mares. Theriogenology 66:1397-1404.

Harada, A., N. Sekido, T. Akahoshi, T. Wada, N. Mukaida, and K. Matsushima. 1994. Essential involvement of interleukin-8 (IL-8) in acute inflammation. J. Leukoc. Biol. 56:559-564.

Herath, S., S. T. Lilly, D. P. Fischer, E. J. Williams, H. Dobson, C. E. Bryant, and I. M. Sheldon. 2009. Bacterial lipopolysaccharide induces an endocrine switch from prostaglandin F2alpha to prostaglandin E2 in bovine endometrium. Endocrinology 150:1912-1920.

Herath, S., E. J. Williams, S. T. Lilly, R. O. Gilbert, H. Dobson, C. E. Bryant, and I. M. Sheldon. 2007. Ovarian follicular cells have innate immune capabilities that modulate their endocrine function. Reproduction 134:683-693.

Herzog, K., K. Strüve, J. P. Kastelic, M. Piechotta, S. E. Ulbrich, C. Pfarrer, K. Shirasuna, T. Shimizu, A. Miyamoto, and H. Bollwein. 2012. Escherichia coli lipopolysaccharide administration transiently suppresses luteal structure and function in diestrous cows. Reproduction 144:467-476.

Kliem, H., B. Berisha, H. H. Meyer, and D. Schams. 2009. Regulatory changes of apoptotic factors in the bovine corpus luteum after induced luteolysis. Mol. Reprod. Dev. 76:220-230.

Lavon, Y., G. Leitner, T. Goshen, R. Braw-Tal, S. Jacoby, and D. Wolfenson. 2008. Exposure to endotoxin during estrus alters the timing of ovulation and hormonal concentrations in cows. Theriogenology 70:956-967.

Levy, N., S. Kobayashi, Z. Roth, D. Wolfenson, A. Miyamoto, and R. Meidan. 2000. Administration of prostaglandin $\mathrm{f}(2$ alpha $)$ during the early bovine luteal phase does not alter the expression of ET-1 and of its type A receptor: A possible cause for corpus luteum refractoriness. Biol. Reprod. 63:377-382.

Livak, K. J., and T. D. Schmittgen. 2001. Analysis of relative gene expression data using real-time quantitative PCR and the 2(-Delta Delta C(T)) method. Methods 25:402-408.

Lopez-Gatius, F. 2003. Is fertility declining in dairy cattle? A retrospective study in northeastern Spain. Theriogenology 60:89-99.

Ma, J. L., Y. H. Zhu, L. Zhang, Z. Y. Zhuge, P. Q. Liu, X. D. Yan, H. S. Gao, and J. F. Wang. 2011. Serum concentration and mRNA expression in milk somatic cells of toll-like receptor 2, toll-like receptor 4 , and cytokines in dairy cows following intramammary inoculation with Escherichia coli. J. Dairy Sci. 94:5903-5912.

Magata, F., M. Horiuchi, R. Echizenya, R. Miura, S. Chiba, M. Matsui, A. Miyamoto, Y. Kobayashi, and T. Shimizu. 2014. Lipopolysaccharide in ovarian follicular fluid influences the steroid production in large follicles of dairy cows. Anim. Reprod. Sci. 144:6-13.

Magata, F., Y. Ishida, A. Miyamoto, H. Furuoka, H. Inokuma, and T. Shimizu. 2015. Comparison of bacterial endotoxin lipopolysaccharide concentrations in the blood, ovarian follicular fluid and uterine fluid: A clinical case of bovine metritis. J. Vet. Med. Sci. $77: 81-84$.

Mateus, L., L. L. da Costa, F. Bernardo, and J. R. Silva. 2002. Influence of puerperal uterine infection on uterine involution and postpartum ovarian activity in dairy cows. Reprod. Domest. Anim. 37:31-35.

Mateus, L., L. Lopes da Costa, P. Diniz, and A. J. Ziecik. 2003. Relationship between endotoxin and prostaglandin (PGE2 and PGFM) concentrations and ovarian function in dairy cows with puerperal endometritis. Anim. Reprod. Sci. 76:143-154.

Mishra, D. P., and A. Dhali. 2007. Endotoxin induces luteal cell apoptosis through the mitochondrial pathway. Prostaglandins Other Lipid Mediat. 83:75-88. 
Mishra, D. P., H. H. Meyer, and B. S. Prakash. 2003. Validation of a sensitive enzymeimmunoassay for 13,14-dihydro-15-keto-PGF2alpha in buffalo plasma and its application for reproductive health status monitoring. Anim. Reprod. Sci. 78:33-46.

Mosher, R. A., C. Wang, P. S. Allen, and J. F. Coetzee. 2013. Comparative effects of castration and dehorning in series or concurrent castration and dehorning procedures on stress responses and production in Holstein calves. J. Anim. Sci. 91:4133-4145.

Mudron, P., K. Herzog, M. Höltershinken, and J. Rehage. 2007. Effects of abdominal surgery on thiobarbituric acid reactive substances and plasma anti-oxidative capacity in dairy cows. J. Vet. Med. A Physiol. Pathol. Clin. Med. 54:441-444.

Murata, H., N. Shimada, and M. Yoshioka. 2004. Current research on acute phase proteins in veterinary diagnosis: An overview. Vet. J. 168:28-40.

Niswender, G. D. 2002. Molecular control of luteal secretion of progesterone. Reproduction 123:333-339.

Nitta, A., K. Shirasuna, S. Nibuno, H. Bollwein, T. Shimizu, and A. Miyamoto. 2013. Downregulation of lymphatic vessel formation factors in PGF2alpha-induced luteolysis in the cow. J. Reprod. Dev. 59:296-301.

Opsomer, G., Y. T. Grohn, J. Hertl, M. Coryn, H. Deluyker, and A. de Kruif. 2000. Risk factors for post partum ovarian dysfunction in high producing dairy cows in Belgium: A field study. Theriogenology 53:841-857.

Peter, A. T., W. T. Bosu, and R. J. DeDecker. 1989. Suppression of preovulatory luteinizing hormone surges in heifers after intrauterine infusions of Escherichia coli endotoxin. Am. J. Vet. Res. 50:368-373.

Peter, A. T., W. T. Bosu, and R. O. Gilbert. 1990. Absorption of Escherichia coli endotoxin (lipopolysaccharide) from the uteri of postpartum dairy cows. Theriogenology 33:1011-1014.

Pistek, V. L., R. W. Furst, H. Kliem, S. Bauersachs, H. H. Meyer, and S. E. Ulbrich. 2013. HOXA10 mRNA expression and promoter DNA methylation in female pig offspring after in utero estradiol17beta exposure. J. Steroid Biochem. Mol. Biol. 138:435-444.

Prieto, M., M. Barrio, L. Quintela, C. Perez-Martin, J. Becerra, M. Vigo, C. Diaz, J. Cainzos, A. Prieto, and F. Fernandez. 2012. Validation of simple method for the interpretation of uterine cytology in cows. Vet Med-Czech 57:360-363.

Sakamoto, K., K. Miwa, T. Ezashi, E. Okuda-Ashitaka, K. Okuda, T. Houtani, T. Sugimoto, S. Ito, and O. Hayaishi. 1995. Expression of mRNA encoding the prostaglandin $\mathrm{F} 2$ alpha receptor in bovine corpora lutea throughout the oestrous cycle and pregnancy. J. Reprod. Fertil. 103:99-105.

Schmittgen, T. D., and K. J. Livak. 2008. Analyzing real-time PCR data by the comparative C(T) method. Nat. Protoc. 3:1101-1108.

Sheldon, I. M., D. E. Noakes, A. N. Rycroft, D. U. Pfeiffer, and H. Dobson. 2002. Influence of uterine bacterial contamination after parturition on ovarian dominant follicle selection and follicle growth and function in cattle. Reproduction 123:837-845.

Shimizu, T., K. Miyauchi, K. Shirasuna, H. Bollwein, F. Magata, C. Murayama, and A. Miyamoto. 2012. Effects of lipopolysaccharide (LPS) and peptidoglycan (PGN) on estradiol production in bovine granulosa cells from small and large follicles. Toxicol. In Vitro 26:1134-1142.

Shirasuna, K., Y. Akabane, N. Beindorff, K. Nagai, M. Sasaki, T. Shimizu, H. Bollwein, R. Meidan, and A. Miyamoto. 2012. Expression of prostaglandin F2alpha (PGF2alpha) receptor and its isoforms in the bovine corpus luteum during the estrous cycle and PGF2alpha-induced luteolysis. Domest. Anim. Endocrinol. 43:227-238.

Shirasuna, K., K. Sasahara, M. Matsui, T. Shimizu, and A. Miyamoto. 2010. Prostaglandin F2alpha differentially affects mRNA expression relating to angiogenesis, vasoactivation and prostaglandins in the early and mid corpus luteum in the cow. J. Reprod. Dev. $56: 428-436$

Souza, A. H., E. P. Silva, A. P. Cunha, A. Gumen, H. Ayres, D. J. Brusveen, J. N. Guenther, and M. C. Wiltbank. 2011. Ultrasonographic evaluation of endometrial thickness near timed AI as a predictor of fertility in high-producing dairy cows. Theriogenology 75:722-733.

Stocco, D. M., and B. J. Clark. 1996. Role of the steroidogenic acute regulatory protein (StAR) in steroidogenesis. Biochem. Pharmacol. 51:197-205.

Suzuki, C., K. Yoshioka, S. Iwamura, and H. Hirose. 2001. Endotoxin induces delayed ovulation following endocrine aberration during the proestrous phase in Holstein heifers. Domest. Anim. Endocrinol. 20:267-278.

Swangchan-Uthai, T., C. R. Lavender, Z. Cheng, A. A. Fouladi-Nashta, and D. C. Wathes. 2012. Time course of defense mechanisms in bovine endometrium in response to lipopolysaccharide. Biol. Reprod. 87:135.

Takeuchi, O., and S. Akira. 2010. Pattern recognition receptors and inflammation. Cell 140:805-820.

Takeuchi, O., K. Hoshino, T. Kawai, H. Sanjo, H. Takada, T. Ogawa, K. Takeda, and S. Akira. 1999. Differential roles of TLR2 and TLR4 in recognition of gram-negative and gram-positive bacterial cell wall components. Immunity 11:443-451.

Thun, R., E. Eggenberger, K. Zerobin, T. Luscher, and W. Vetter. 1981. Twenty-four-hour secretory pattern of cortisol in the bull: Evidence of episodic secretion and circadian rhythm. Endocrinology 109:2208-2212.

Trevisol, E., J. C. Ferreira, C. L. Ackermann, F. C. Destro, W. C. Marques Filho, A. S. Carmagos, M. V. Biehl, J. B. do Amaral, J. C. de Figueiredo Pantoja, R. Sartori, and J. C. Ferreira. 2015. Luteal changes after treatment with sub-luteolytic doses of prostaglandin (cloprostenol sodium) in cattle. Anim. Reprod. Sci. 153:8-12.

Tsai, S. J., K. Kot, O. J. Ginther, and M. C. Wiltbank. 2001. Temporal gene expression in bovine corpora lutea after treatment with PGF2alpha based on serial biopsies in vivo. Reproduction 121:905-913

Tsousis, G., R. Sharifi, and M. Hoedemaker. 2009. Associations between the clinical signs of chronic endometritis with ovarian cysts and body condition loss in German Holstein Friesian cows. J. Vet. Sci. 10:337-341.

Walsh, S. W., E. J. Williams, and A. C. Evans. 2011. A review of the causes of poor fertility in high milk producing dairy cows. Anim. Reprod. Sci. 123:127-138.

Williams, E. J., D. P. Fischer, D. E. Noakes, G. C. England, A. Rycroft, H. Dobson, and I. M. Sheldon. 2007. The relationship between uterine pathogen growth density and ovarian function in the postpartum dairy cow. Theriogenology 68:549-559.

Williams, E. J., K. Sibley, A. N. Miller, E. A. Lane, J. Fishwick, D. M. Nash, S. Herath, G. C. England, H. Dobson, and I. M. Sheldon. 2008. The effect of Escherichia coli lipopolysaccharide and tumour necrosis factor alpha on ovarian function. Am. J. Reprod. Immunol. 60:462-473. 